\title{
Development of Electronic Module Text Writing Procedure Discovery Based Learning in High School
}

\author{
D Asri', S Ramadhan ${ }^{2}$, Y Asri ${ }^{2}$ \\ $\left\{\right.$ deciasri1@gmail.com $\left.{ }^{1}\right\}$ \\ ${ }^{1}$ Master Program Student, Universitas Negeri Padang, Padang, Indonesia \\ ${ }^{2}$ Faculty of Language and Art, Universitas Negeri Padang, Padang, Indonesia
}

\begin{abstract}
The purpose of this study was to describe the process of developing an elearning module to write text-based procedures of discovery learning is valid (in terms of content, presentation, linguistic and kegrafikaan), practical (in terms of ease of use and compliance with time), and effective ( visits from student activity, learning outcomes, and affective students) used in class XI student of SMA. This type of research is the research and development (research and development). Development model used is the model 4-D (defining, Design, development and deployment. The subjects were students class XI. IPA 1 SMAN 7 Padang totaling 29 people. The research data consists of quantitative and qualitative data. Qualitative data were collected through questionnaires filling e-module validation, questionnaire practicalities of e-module, and student activity observation sheet. Quantitative data obtained from the students in learning writing procedure text. The results of this study indicate that the e-learning modules for writing text-based discovery learning procedures generated are valid, practical, and effective. This was evidenced from the results validity, practicalities, and the effectiveness of the e-module.
\end{abstract}

Keywords: Electronic module, Text Writing Procedure Discovery, High School

\section{Introduction}

Language skills of students in Indonesia have become essential to develop. Students' understanding of a text supported by the activities of writing, reading, listening, listening, observing, and so forth. Through the activities of the students will understand the characteristics of the text, put forward the information contained therein, and be able to apply the information useful for him [1]. One of the types of texts studied in subjects Indonesian is the text of the procedure. Text is text direction procedure or teach about the steps and instructions to carry out something in a sequence [2][3].

Facts on the ground indicate that the students' ability to write text procedure is still low. This can be evidenced by the results of interviews conducted with Indonesian teacher at SMAN 7 Padang Ibu Dra. Afrienituti. Based on the interview there are some things that become problems in writing the text of the procedure. First, not all students are active in the learning process. Second, the learning method is a method often used by teachers lecture, discussion, and question and answer, so students are less motivated. Third, the media used less attractive teacher. Fourth, learning resources that students use is limited to one student book 
published by Kemendikbud. Fifth, students when writing text often constrained procedure in determining the structure of language and linguistic characteristics of the text.

Based on the problems that have been described, it is necessary alternatives to problem solving and innovation in developing instructional materials that support learning curriculum text-based procedure in 2013 [4]. Teachers and students also expect their companion instructional materials for students to deepen the understanding of matter in the house by way of self-learning [5][6]. Popular teaching materials developed is e-modules. E-module is one form of teaching materials in the era education influenced by the industrial revolution 4.0. 4.0 Education is education utilizing digital technology in the learning process known as cyber systems (cyber system). The system is able to make the learning process can take place continuously without limits of space and time limits.

Research on e-module the last few years this has been done in the field of education in various countries such as Japan, Taiwan, Malaysia, Saudi Arabia, USA, Bosnia, and Iran, and Thailand. Based on these studies e-modules can make the learning process more interesting, interactive, it can be done anytime and anywhere and can improve the quality of teaching, and help students learn without requiring a lot of costs [7][8][9][10][11][12][13][14][15]. Emodule is different from learning modules developed earlier. The specificity of this e-module covers several aspects, is as follows. First, e-module is presented in the form of learning applications that can be read by devices and computers. So that students can read materials learning anywhere and anytime. Second, e-module in which there is video, animation, and audio learning in the absence of a print module. Third, e-module in use juxtaposed with Edmodo, the online virtual world class. Fourth, the exercises contained in the e-module can be directly assessed by the application.

The development of e-modules would be applying the learning model discovery learning. Past research has shown that the use of model of discovery learning can improve student learning outcomes. The study has been conducted in various countries such as India, Turkey, Arizona, and Indonesia, and Taiwan. In India, the students perform the discovery process through media designed models. Discovery learning can stimulate the reader to experiment in the learning process [16].

Application discovery model of learning in developing active student learning is to find yourself, to investigate itself, then the results will be long-lasting in the minds of students. The position of teachers in the classroom is as supervising and directing the learning activities that correspond with the purpose [17]. Based on these realities, it is important to develop teaching materials in the form of e-learning modules for writing text-based discovery learning procedures in class XI SMA. E-module is expected to develop creativity and innovation of students in learning.

\section{Method}

This type of research is the development research (research and development). This study will develop e-learning modules for writing text procedure. The process of developing emodules implemented following the model of the 4-D [18]. Model 4-D consists of four stages of development, ie define, design, develop, and disseminate. Subject test this module is a class XI student of SMAN in Padang. This study is limited in high school that has used curriculum 2013 revised edition. The school was SMAN 7 Padang. The data generated from the test in the form of qualitative and quantitative data. The instrument used to collect data in the validation by experts who understand it first. The instrument used consisted of the questionnaire, questionnaire analysis of students, curriculum analysis questionnaire, questionnaire analysis of 
the concept, product validation sheet, sheet practicalities of e-module, student activity observation sheet, write performance testing, assessment rubrics write performance tests, and questionnaires deployment of e- module. Data analysis techniques implemented by describing the validity, practicalities, and the effectiveness of e-learning modules for writing text-based discovery learning procedure XI students SMA N 7 Padang. From the results of the study were analyzed using descriptive statistics to obtain an average value and as a percentage of all required details. Data analysis was conducted to determine the validity, practicalities, and the effectiveness of e-learning modules.

\section{Result and Discussion}

\subsection{The definition phase (define)}

Disadvantages associated with writing text procedure, which is a source of learning. Therefore, students need to have a practical learning resources to support learning writing text procedure. Thus, students can understand the material and do the exercises properly write text procedure. Students in need of learning resources according to their characteristics, both in terms of use of letters, pictures, color combination, to the use of communicative language. One of the learning resources that can be used is an e-learning module. E-learning modules should be in accordance with the needs of students, and can raise students' motivation to learn.

\subsection{Stage design (design)}

Preparation of e-module begins by searching various references required. After that, do the design frame (outline) e-module, and designed it to have an attractive appearance. Framework of an e-learning module is adapted to discovery learning. E-modules that are designed based on the theory of the structure of e-modules, namely the introduction, learning activities, and evaluation.

\subsection{Development stage (develop)}

\subsubsection{Validity test}

E-module validated by two experts who have determined, that one lecturer Indonesian language and literature, and one lecturer in Education Technology. Aspects of validation by the validator consists of four types, namely the feasibility of the content, language, presentation feasibility, and graphic.

Table 1. Results of the e-module validation strategies

\begin{tabular}{llll}
\hline Rated aspect & Acquisition of score & Validity $(\%)$ & Category \\
\hline $\begin{array}{l}\text { Feasibility contents of the e- } \\
\text { module }\end{array}$ & 91.0 & 94.79 & Very valid \\
Language e-module & 32.0 & & \\
Presentation of e-module & 99.5 & 100.00 & Very valid \\
Graphic of e-modul & 49.0 & 99.50 & Very valid \\
Total & 271.5 & 87.50 & Very valid \\
\hline
\end{tabular}

Based on analysis of these data, the validity of the e-module obtained Skilled Writing Text Procedure of $95.59 \%$ with a very valid category. Translation of the validity of each of these aspects are validated as follows. First, validate the feasibility aspect of the e-module of 
$94.79 \%$ with a very valid category. Second, the validation aspects of language e-modules of $100 \%$ with a very valid category. Third, the validation aspects of the presentation of the emodule of $99.5 \%$ to the category of very valid. Fourth, the validation aspects of e-module kegrafikaan of $87.5 \%$ to the category of very valid.

\subsubsection{Practicality test}

Practicalities of e-modules useful to know whether the e-modules designed a practical emodule used by students.

Table 2. Data description practicalities e-module by teacher

\begin{tabular}{|c|c|c|c|c|}
\hline Aspects rating & $\begin{array}{l}\text { Total } \\
\text { score }\end{array}$ & $\begin{array}{l}\text { Maximun } \\
\text { score }\end{array}$ & $\begin{array}{l}\text { Practicality value } \\
(\%)\end{array}$ & Category \\
\hline Ease of use & 50 & 60 & 83.33 & Very practical \\
\hline Time used & 10 & 12 & 83.33 & Very practical \\
\hline $\begin{array}{l}\text { Practicality } \\
\text { entire e-module }\end{array}$ & 60 & 72 & 83.33 & Very practical \\
\hline
\end{tabular}

After conducting an analysis of the practicalities of e-module questionnaires filled out by the practitioner, the value of the practicalities of $83.33 \%$ with a very practical category. The value obtained from calculating a score of each indicator practicality. First, from the ease of use has a value practicality of $83.33 \%$ with a very practical category. Second, from the time that you use are rated practicality of $83.33 \%$ with a very practical category.

Table 4. Data description practicalities e-module by student

\begin{tabular}{|c|c|c|c|c|c|c|}
\hline Aspect rating & & & Total score & $\begin{array}{l}\text { Practicalities } \\
(\%)\end{array}$ & value & Category \\
\hline Ease of use & & & 1157.08 & 82.64 & & Very practical \\
\hline Time used & & & 249.70 & 83.23 & & Very practical \\
\hline $\begin{array}{l}\text { Practicality } \\
\text { module }\end{array}$ & entire & e- & 1406.78 & 82.75 & & Very practical \\
\hline
\end{tabular}

After conducting an analysis of the practicalities of e-module questionnaires filled out by the students, the value of the practicalities of $82.75 \%$ with a very practical category. The value obtained from calculating a score of each indicator practicality. First, from the ease of use has a value practicality of $82.64 \%$ with a very practical category. Second, from the time that you use are rated practicality of $83.23 \%$ with a very practical category.

\subsubsection{Effectiveness test}

The effectiveness of the e-module is the final stage of development. The effectiveness of the e-module is done in two ways. First, assess the results of students' writing text procedure. after learning to write text procedure is finished, students follow the text writing performance test procedures. Knowledge assessment data writing procedure text can be seen in the following figure. 


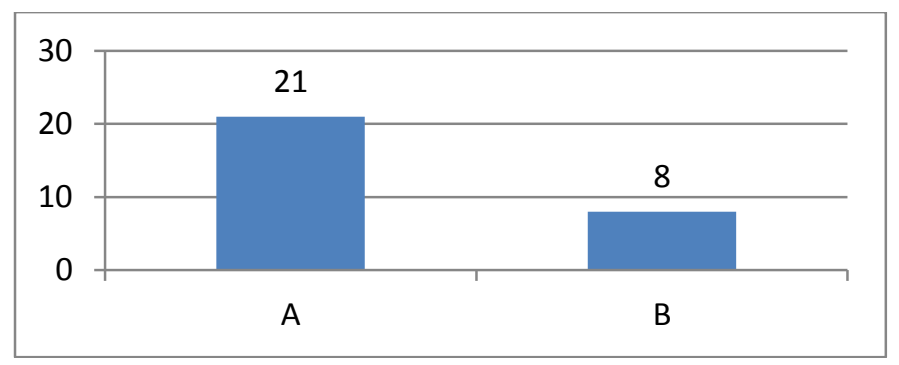

Figure 1. Histogram test knowledge assessment procedure

Furthermore, the overall average value of the knowledge acquired by the students is $87.51 \%$ change value A. Thus, we can conclude that through learning the text by using the procedure effective e-module to achieve the learning outcomes of students to meet the standards above the minimal completeness criteria. Data writing skills assessment procedure text can be seen in the following figure.

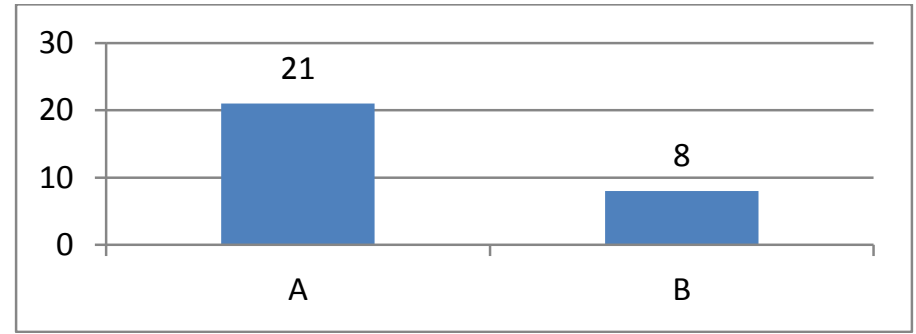

Figure 2. Histogram text rate performance test procedure

Furthermore, the overall average value of the knowledge acquired by the students is 89.68 changes the value of $\mathrm{A}$.

\subsection{Deployment phase (disseminate)}

Spreading the e-module is done in two stages. The first phase is the deployment of emodules are restricted to a teacher other than a collaborator on the class trial, the teacher who taught in other classes. Teachers receive as much as a single file or an e-module soft copy given to the teacher. In addition, teachers were also given questionnaires about the spread of emodules. The second phase of the deployment of e-modules to the students is done by distributing files or softcopy e-modules as the number of students in the class.

Basically e-module is intended for students to be able to learn independently. E-modules that have been designed an e-learning module is used for independently. So that students try to understand the material appropriate procedure text learning path and can carry out activities in accordance with the procedure text write own abilities.

Learning discovery learning can be done in groups or independently. However, in elearning modules, all activities are conducted independently. This was done to maximize all students' ability to understand and write text procedure. In addition, an independent learning project outcomes are intended to do, which resulted in a product that is expected of all students can participate in the final results of e-learning modules were launched. 
Learning using e-modules is more portable and requires lighter storage space so that it can be carried anywhere at any time. Besides, e-module content is more dynamic and interactive. This benefits the link so users can refer to certain pieces of information or access any part of the e-module easily. Last but not least, e-modules are highly integrated with multimedia elements, such as audio, background music, animation and video that make reading not only more interesting but easier to understand [19][20][21][22].

\section{Conclusions}

Based on the results of the development that has been done, we can conclude the following points. First, the process of development of e-modules on stagedefining (Define). At this stage concluded that there are several problems that hinder the achievement of the objectives of learning to write text procedures, the limited teaching materials used. This has an impact on learning outcomes of students who still have an average below the minimum completeness criteria (KKM). Second, the process of the development of e-module at the design stage (design). At this stage the framework of e-module design and drafting e-modules.play framework of the e-learning module consists of at least hint learning, competency to be achieved, content, exercises and worksheets. Third, the process of development of e-modules during the development stage (develop). The validity of the e-modules are drawn from the results of validation by the experts of the four aspects of the validation e-modules, namely the feasibility aspect of the content, language, presentation, and kegrafikaan. It can be seen from the validity of the e-learning module is the acquisition value of the validity of the e-module as big as 95.59 categorized as very valid. Fourth, the process of development of e-module in the deployment phase (disseminate). E-module deployment phase three stages. (1) The spread to other teachers than teachers in SMA research collaborators 7 Padang. (2) Distribution of students by submitting an e-learning module to the school library, the library SMAN 7 Padang. (3) The spread to friends.

\section{Acknowledgments}

A sincere thanks goes to students and teachers of Padang 7 High School. Researchers are also indebted to the Directorate General of Higher Education for the provision of research grants.

\section{References}

[1] S. Farboy, "Penerapan metode cooperative integrated reading and composition (circ) untuk meningkatkan kemampuan menemukan gagasan utama sebuah teks pada siswa kelas VII di SMP Negeri 3 Batu tahun ajaran 2008/2009,” J. Artik., vol. 7, no. 1, pp. 415-431, 2009.

[2] Mahsun, Teks dalam pembelajaran bahasa indonesia kurikulum 2013. Jakarta: Raja Grafindo Persada, 2014.

[3] E. T. Priyatni, Desain pembelajaran bahasa indonesia dalam kurikulum 2013. Jakarta: Bumi Aksara, 2014.

[4] A. Sorraya, "Pengembangan bahan ajar teks prosedur kompleks dalam pembelajaran bahasa Indonesia untuk kelas X SMK," Nosi, vol. 2, no. 2, pp. 13-28, 2014.

[5] V. Indriyani and S. Ramadhan, "The development teaching of writing fable text module with project based learning (PjBL) containing characters," in Advances in Social Science, Education and Humanities Research, 2017, vol. 104, pp. 16-21. 
[6] S. Ramadhan, Y. Asri, and V. Indriyani, "Learning Module Design Writing Argumentative Text Based Problem-Based Learning," in Advances in Social Science, Education and Humanities Research, 2018, vol. 263, pp. 194-200.

[7] K. Mouri, N. Uosaki, and H. Ogata, "Learning analytics for supporting seamless language learning using e-book with ubiquitous learning system," Educ. Technol. Soc., vol. 21, no. 2, pp. 150-163, 2018.

[8] K. Mouri, F. Okubo, A. Shimada, and H. Agata, "Profiling high-achieving students for e-book-based learning analytics," in International Workshop on Learning Analytics Across Physical and Digital Spaces, 2016.

[9] Y. N. Su, C. C. Kao, C. C. Hsu, L. C. Pan, S. C. Cheng, and Y. M. Huang, "How does mozart's music affect children's reading? the evidence from learning anxiety and reading rates with e-books," Educ. Technol. Soc., vol. 20, no. 2, pp. 101-112, 2017.

[10] J. Lin and H. K. Lin, "User acceptance in a computer-supported collaborative learning (CSCL) environment with social network awareness (SNA) support," Australas. J. Educ. Technol., vol. 35, no. 1, pp. 100-115, 2019.

[11] Sumiyatun, "Pengembangan e-modul pembelajaran cerita pendek berbasis lectora inspire sebagai bahan belajar mandiri peserta didik kelas XI MAN 2 Batu," Nosi, vol. 5, no. 2, pp. 162-174, 2017.

[12] T. Doering, L. Pereira, and L. Kueechler, "The use of e-textbooks in higher education : A case study," E-Leader Berlin, 2012.

[13] T. Jones and C. Brown, "Reading engagement: A comparison between e-book and traditional print books in an elementary classroom," Int. J. Instr., vol. 4, no. 2, pp. 522, 2011.

[14] L. Tania and J. Susilowibowo, "Pengembangan bahan ajar e-modul sebagai pendukung pembelajaran kurikulum 2013 pada materi ayat jurnal penyesuaian perusahaan jasa siswa kelas X akuntansi SMK Negeri 1 Surabaya," J. Account. Educ. Stud. Program, Fac. Econ. State Univ. Surabaya, pp. 1-9, 2016.

[15] A. S. Winarko, W. Sunarno, and M. Masykuri, "Pengembangan modul elektronik berbasis poei (prediksi, observasi, eksperimen, interpretasi) pada materi sistem indra kelas XI SMA Negeri 3 ponorogo,” Bioedukasi, vol. 6, no. 2, pp. 58-75, 2013.

[16] B. Plangsorn and S. Poopan, "Development of producing and using e-books competencies of teachers in Chachengsao, Thailand," World J. Educ. Technol. Curr. Issues, vol. 09, no. 02, pp. 112-117, 2017.

[17] A. Kistian, D. Armanto, and A. Sudrajat, "The effect of discovery learning method on the math learning of the V SDN 18 students of Banda Aceh, Indonesia," Br. J. Educ., vol. 5, no. 11, pp. 1-11, 2017.

[18] Trianto, Mendesain model pembelajaran inovatif-progresif. Jakarta: Kencana, 2012.

[19] K. T. Anuradha and H. S. Usha, "Use of e-books in an academic and research environment - A case study from the Indian Institute of Science," Progr. Electron. Libr. Inf. Syst., vol. 40, no. 1, pp. 48-62, 2015.

[20] A. Bonime and C. Pohlmann, Writing for new media: the essential guide to writing for interactive media, cd-roms and the web. New Jersey: John Wiley \& Sons, 1998.

[21] J. O. Borchers, "Electronic books: definition, genres, interaction design patterns," in Workshop on Electronic Books, CHI'99 International Conference on Human Factors in Computing Systems, Pittsburgh, PA, 1999.

[22] S. A. Long, "The case for e-books: an introduction," New Libr. World, vol. 104, no. 1, pp. 29-32, 2003. 
